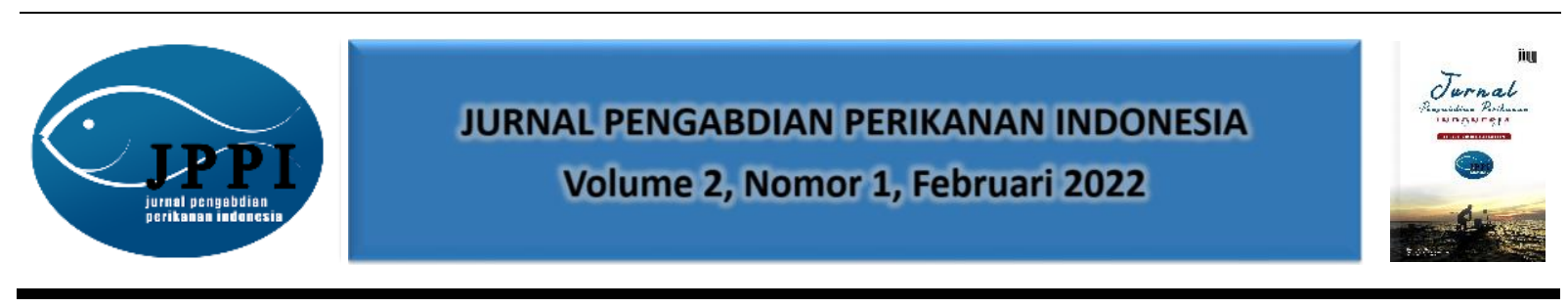

\title{
INTEGRASI PEMANFAATAN PAKAN FORMULASI DAN SISTEM BUDIDAYA RESIRKULASI UNTUK INTENSIFIKASI PRODUKSI BENIH IKAN GURAME DAN PENINGKATAN PENDAPATAN MASYARAKAT DI DESA MARGACINTA, KONAWE SELATAN
}

\author{
Irwan Junaidi Effendy ${ }^{1^{*}}$, Rosmawati ${ }^{2}$, Syamsul Kamri ${ }^{3}$ \\ ${ }^{1} J u r u s a n$ Budidaya Perairan Universitas Halu Oleo, ${ }^{2} \mathrm{Jurusan}$ Agrobisnis Perikanan Universitas Halu \\ Oleo, ${ }^{3}$ Program Studi Perikanan Tangkap, Universitas Halu Oleo
}

Gedung LT. 3 Fakultas Perikanan dan Ilmu Kelautan, Universitas Halu Oleo, Kampus Hijau Bumi Tridharma, Kambu, Kota Kendari, Sulawesi Tenggara, 93132

*Alamat korespondensi : irwanjunaidieffendy@uho.ac.id

\begin{abstract}
Keyword: Abstrak :
Gurame, Intensifikasi budidaya ikan gurame pada UKM (Kelompok Pembudidaya Carper) benih, mitra Program Kemitraan Masyarakat (PKM) sangat dibutuhkan untuk memenuhi system permintaan benih yang semakin besar. Intensifikasi ini dilakukan dengan budidaya mengingtegrasikan system budidaya resirkulasi dan penggunaan pakan formulasi resirkulasi, komersial. Penerapan sistem budidaya resirkulasi diterapkan karena pembudidaya pakan memiliki lahan dan air terbatas terutama di musim kemarau sedangkan pemanfaatan formulasi, pakan formulasi pada induk dan benih dilakukan untuk mendukung dan intensifikasi mempercepat pematangan gonad, proses pemijahan, produksi benih dan produksi pembesaran benih. Kegiatan ini bertujuan untuk meningkatkan produksi dan menghasilkan benih berkualitas sehingga meningkatkan pendapatan UKM Mitra. Kegiatan ini dilaksanakan di Desa Margacinta, Kab. Konawe Selatan, Prov. Sulawesi Tenggara. Produksi dan budidaya massal benih dilakukan menggunakan bak fiber ukuran 1 ton dan diterapkan system pendederan bertahap dan setiap tahap dilakukan seleksi untuk memperoleh ukuran benih standar. Kegiatan percontohan intensifikasi budidaya gurame pada PKM ini, telah menunjukkan hasil produksi dan budidaya massal benih gurame dengan pertumbuhan dan sintasan yang dihasilkan tinggi pada setiap tahap pendederan serta memberikan keuntungan yang sangat memuaskan bagi Mitra PKM. Kegiatan PKM ini telah memberikan manfaat dan hasil yang sangat memuaskan yaitu mempermudah manajemen produksi benih; mulai dari pengontrolan, pemberian pakan dan panen; meningkatkan produksi benih dan pendapatan, mempermudah manajemen pemesaran benih dan mengatasi masalah kekurangan air pada musim kemarau sehingga produksi benih berkelanjutan sepanjang tahun.
\end{abstract}


Panduan Sitasi (APPA $7^{\text {th }}$ edition) :

Effendy, I. J., Rosmawati, \& Kamri, S. (2022). Integrasi Pemanfaatan Pakan Formulasi Dan Sistem Budidaya Resirkulasi Untuk Intensifikasi Produksi Benih Ikan Gurame Dan Peningkatan Pendapatan Masyarakat Di Desa Margacinta, Konawe Selatan. Jurnal Pengabdian Perikanan Indonesia, 2(1), 25-34. https://doi.org/10.29303/jppi.v2i1.504.

\section{PENDAHULUAN}

Intensifikasi budidaya ikan gurame dengan mengintegrasikan penggunaan pakan formulasi dengan system akuakultur resirkulasi (RAS/resirculating aquaculture system) akan dilakukan pada progam PKM ini. Mitra PKM adalah Kelompok Pembudidaya Ikan yang memiliki lahan produksi dan fasilitas budidaya serta sumberdaya alam air yang tersedia secara alami. Salah satu upaya terbaru yang dilakukan terkait hal itu adalah melakukan intesifikasi budidaya gurame di desa margacinta, karena daerah tersebut didukung sumber daya alam seperti ketersediaan lahan, air maupun kesiapan calon UKM mitra / masyarakat untuk melakukan kegiatan tersebut.

Intensifikasi ini dilakukan dengan mengingtegrasikan system budidaya resirkulasi dan penggunaan pakan formulasi komersial. Penerapan sistem budidaya resirkulasi diterapkan karena pembudidaya memiliki lahan dan air terbatas terutama di musim kemarau sedangkan pemanfaatan pakan formulasi pada induk dan benih dilakukan untuk mendukung dan mempercepat pematangan gonad, proses pemijahan, produksi benih dan pembesaran benih. Kegiatan ini bertujuan untuk meningkatkan produksi dan menghasilkan benih berkualitas sehingga meningkatkan pendapatan UKM Mitra.

Kegiatan PKM ini telah memberikan manfaat dan hasil yang sangat memuaskan yaitu mempermudah manajemen produksi benih; mulai dari pengontrolan, pemberian pakan dan panen; meningkatkan produksi benih dan pendapatan, mempermudah manajemen pemesaran benih dan mengatasi masalah kekurangan air pada musim kemarau sehingga produksi benih berkelanjutan sepanjang tahun.

Pakan formulasi yang akan digunakan pada kegiatan ini untuk pemeliharaan induk ikan gurame sampai menghasilkan benih dan untuk pemeliharan benih sampai dewasa yang dilakukan dengan system RAS. Integrasi penerapan teknologitersebut dapat mengatasi masalah utama yang dihadapi oleh mitra dalam kegiatan budidaya gurame yaitu mahalnya pakan berkualitas dan debit air yang berkurang karena pengaruh musim dapat diatasi dengan penerapan system RAS pada kolam budidaya. Keunggulan RAS adalah akan meningkatkan kualitas air, meningkatkan padat tebar ikan, meningkat sintasan, meningkatkan pendapatan dan kegiatan akan berkelanjutan(Sulistyo et al., 2016: P3TKP, 2013):Dalsgaard et al., 2013,Drengstig, \& Bergheim, 2013). Pengembangan tersebut, bertujuan untuk menggenjot produksi dan sekaligus menaikkan pendapatan para pembudidaya yang tersebar di berbagai daerah.

Pada system Resisrkulasi RAS yang dimodifikasi dengan penambahan filter spons, bioball, pecahan karang, pasir dan arang yang digunakan, ini dimaksudkan untuk mendukung kualitas air yang baik untuk produksi benih yang akan dihasilkan. Penerapan pemanfaatan pakan formulasi diintegrasikan dengan teknologi system budidaya Resirkulasi / RAS yang telah pada berbagai spesies. Penerapan system budidaya resirkulasi akan mengikuti dan memodofikasi metode sistem akuakultur Resiskulasi (Dalsgaard et al, 2013: Qiu et al, 2016: Zhu et al., 2016: Allen, 2017: Thesiana dan Pamungkas (2015) ,34 Sulistyo et al (2016), Jeffery et al (2011). Susunan media filter mekanik dan filter biologi akan dilakukan mengikuti dan memodifikasi (Thesiana dan Pamungkas (2015) dan Sulistyo et al (2016). Adapun instalasi system RAS yang akan diterapkan pada kegiatan PKM ini, 
seperti pada Gambar 1. Modifikasi yang dilakukan adalah melakukan budidaya azolla dan talas bersama cacing sutra, terintergrasi pada system budidaya resirkulasi pemeliharaan induk dengan memanfaatkan air yang meluap dan buangan pada system filter mekanik dan biologi mengalir pada bak azolla, juga partikulat yang tertampung pada filter mekanik akan dibuang pada tempat budidaya talas dan cacing sebagai pupuk organik untuk tumbuh.

Dari kegiatan ini diharapkan bahwa integrasi penerapan penggunaan pakan formulasi dan system budidaya resirkulas untuk digunakan oleh Mitra PKM yaitu kelompok pembudidaya ikan dapat tersosiasilasi dan dimanfaatkan secara maksimal untuk meningkatkan produksi ikan Gurame, pendapatan dan meningkatkan ketrampilan serta kesejahteraan masyarakat di Desa Margacinta dan

\section{METODE KEGIATAN}

Kegiatan ini dilaksanakan di Desa Margacinta, Kab. Konawe Selatan, Prov. Sulawesi Tenggara. Pembuatan demplot dan pendampingan penerapan system budidaya resirkulasi untuk budidaya induk dan benih Gurame dilaakukan pada UKM mitra. Produksi dan budidaya massal benih dilakukan menggunakan bak fiber ukuran 1 ton yang disusun pada system budidaya resirkulasi. Pada kegiatan ini diterapkan system pendederan bertahap dan setiap tahap panen dilakukan sortir benih untuk memperoleh hasil ukuran benih yang seragam.

Pelaksanaan Program Kemitraan Masyarakat menggunakan metode pelatihan pada demplot system budidaya resirkulasi dan pendampingan budidaya benih gurame, sebagai berikut:

1. Pembuatan demplot sistem resirkulasi (sistematika system resirkulasi (Gambar 1) untuk pemeliharaan induk dan pembesaran benih dengan tahapan:

a. pembuatan demplot dan instalasi sistem resirkulasi untuk induk gurame pada kolam

b. panen telur gurame dan pemeliharaan benih gurame 0-50 hari

2. Demplot system budidaya resirkulasi dan pendampingan pemeliharaan benih umur 2,3 dan 4 bulan pada system resirkulasi dengan kepadatan 600 dan 800 benih dan diberi pakan formlasi komersial

3. Panen dan seleksi/sortir benih untuk penjualan

Alat yang digunakan dalam pembuatan demplot system budidaya resirkulasi untuk benih gurame adalah sebahai berikut: Bak fiber kapasitas 1000 liter 6 buah ( 5 buah untuk budidaya benih dan 1 buah untuk mendistribusikaan air secara grafitasi pada 5 bak tempat pemeliharaan benih ikan gurame. 1 bak ukuran 800 liter digunakan sebagai bak tempat filter 1 (untuk menampung partikel sisa pakan dan limbah kotoran benih gurame (sebagai bak sedimentasi dan bak filter biologi). (Wadah filter yang digunakan berkapasitas 70 liter berisi: pasir, bioball, pecahan karang dan filter spon serta waring hijau) dalam bak juga ditempatkan arang tempurung dengan berat 5 kg. Dari bak 800 liter setelah penyaringan air kemudian di pompa menuju bak 1000 liter yang di dalam bak dipasang filter kapasitas 70 liter berisi pasir, bioball dan arang dan kain spon. Air kemudian didistribusikan secara gravitasi pada 5 bak pemeliharaan benih berukuran 1000 liter. Pompa yang digunakan pada unit demplot budidaya benih berkapasitas 2500 liter per jam untuk meresirkulasi air pada system. Penambahan air setiap bulan ke dalam sistem dilakukan dalam jumlah yang relatif sedikit, yaitu hanya mengganti volume air yang hilang akibat penguapan, rembesan dan pembersihan dasar kolam

Desain demplot sistem budidaya resirkulasi yang diterapkan pada kegiatan ini seperti pada gambar berikut: 


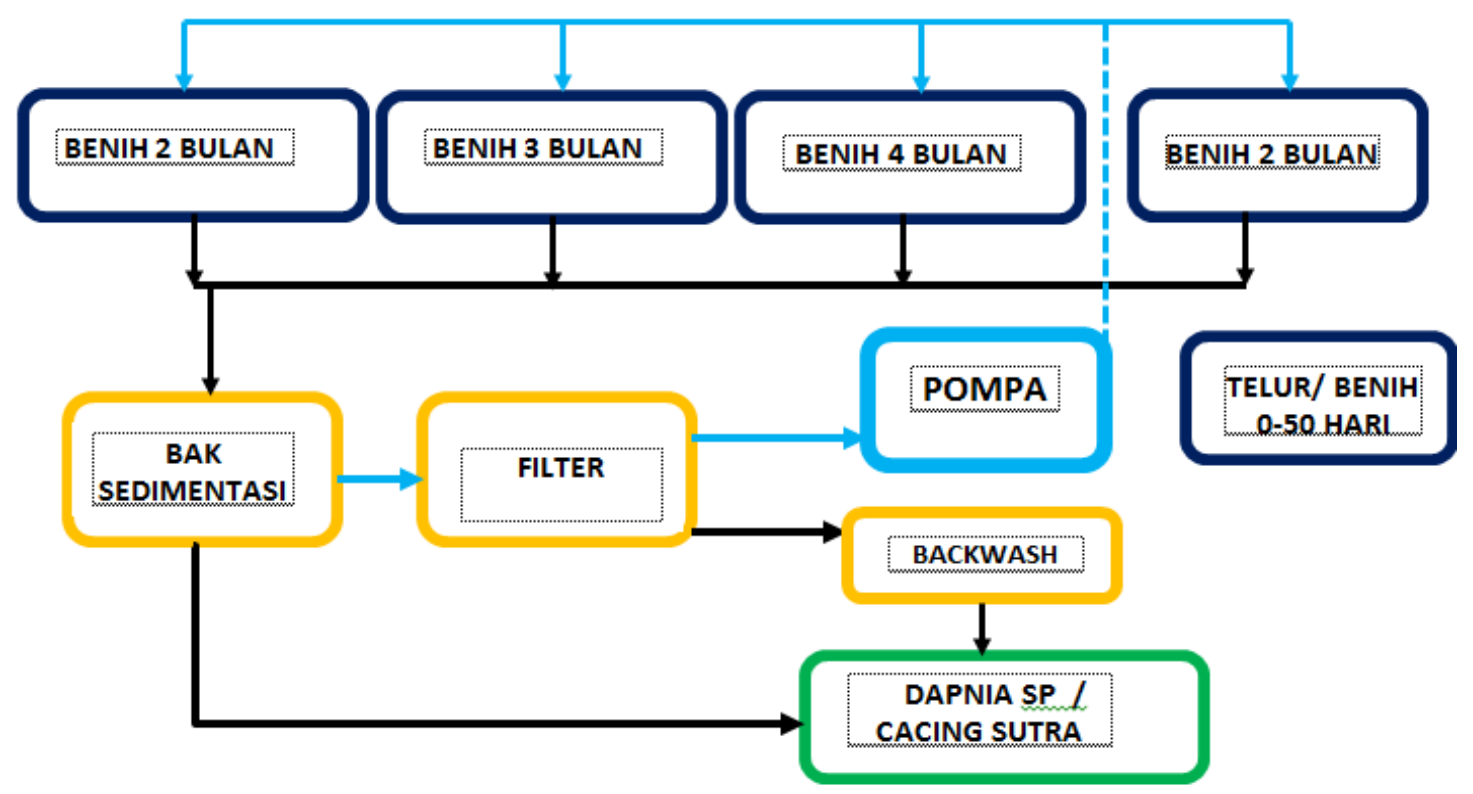

Gambar 1. Diagram Skematik Sistem Akuakultur Resiskulasi yang Diterapkan pada Kegiatan Program Kemitraan masyarakat.

Pada system resirkulasi yang digunakan untuk pemeliharaan benih gurame dilakukan dengan memodifikasi desain sistem resirkulasi sehingga kondisi system resirkulasi memungkinkan untuk membuang limbah padatan, limbah ammonia dan dapat menghasilkan air didaur ulang yang baik untuk ikan yang dibudidayakan. Penggunaan system filter dan pengadaan aerasi dilakukan untuk memastikan system resirkulasi yang digunakan dapat bekerja dengan baik.

\section{HASIL DAN PEMBAHASAN}

1. Pembuatan demplot system resirkulasi untuk induk dan benih ikan gurame

Pembuatan Demplot system resirkulasi dan tahap budidaya ikan gurami dengan system budidaya resirkulasi dan penggunaan pakan formulasi yang diterapkan pada mitra UKM kelompok pembudidaya ikan adalah sebagai berikut kedalam beberapa tahapan berikut:

a. Pada Demplot system Resirkulasi (Gambar 2) kolam induk kelompok pembudidaya memelihara 12 induk betina dan 3 induk jantan. Pakan yang diberikan adalah pakan komersial dan diberi pakan tambahan daun santé / talas. Induk dipelihara sampai menghasilkan benih. Pada kolam ditempatkan 4 sarang berbentuk kerucut untuk tempat induk bertelur.

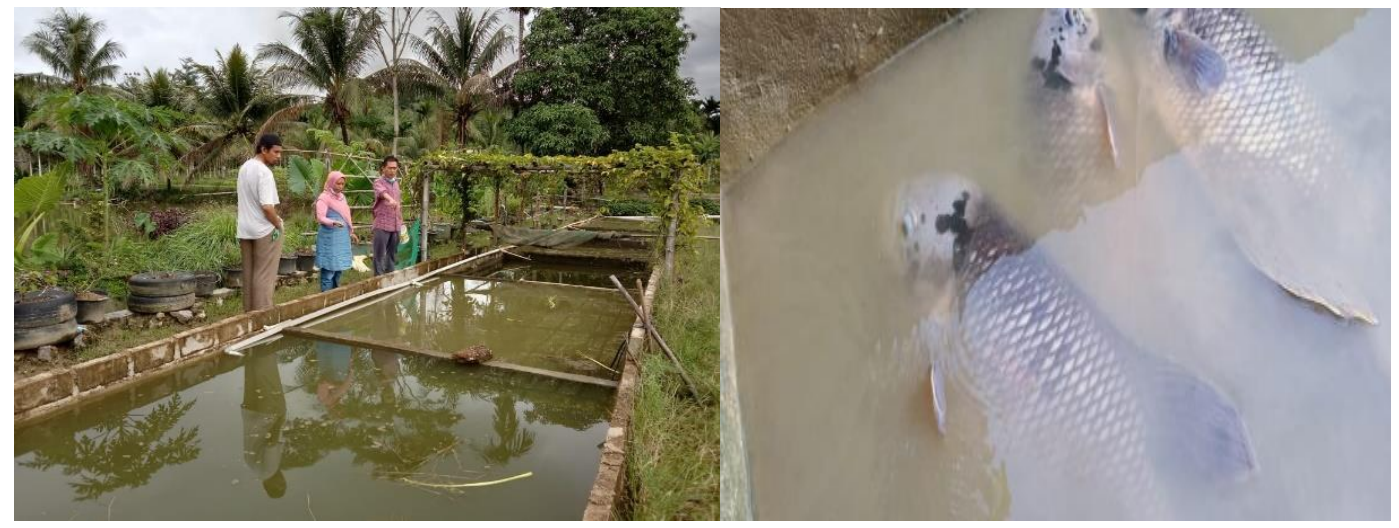

Gambar 2. Demplot dan instalasi sistem resirkulasi untuk induk gurame pada kolam 
b. Tahap pembenihan yang mencakup tahap pemijahan, penetesan telur dan perawatan larva. Telur yang telah menetas dari induknya dipelihara hingga menjadi larva dengan berat 0,1-0,2 gram selama 45 hari menggunakan pakan alami Moina sp (kutu air) selanjutnya di beri pakan formulasi komersial Prima Feed (pf 500). Pemberian pakan secara ad libitum dilakukan setiap hari pada pukul 08.00 dan pukul 16.00. Diperkirakan selama masa kegiatan sampai bulan Oktober semua induk memijah 8 ekor sehingga diperkirakan minimal 10000 benih dihasilkan setelah dipelihara pada bak / kolam larva/benih selama 1-2 bulan (Gambar 3).
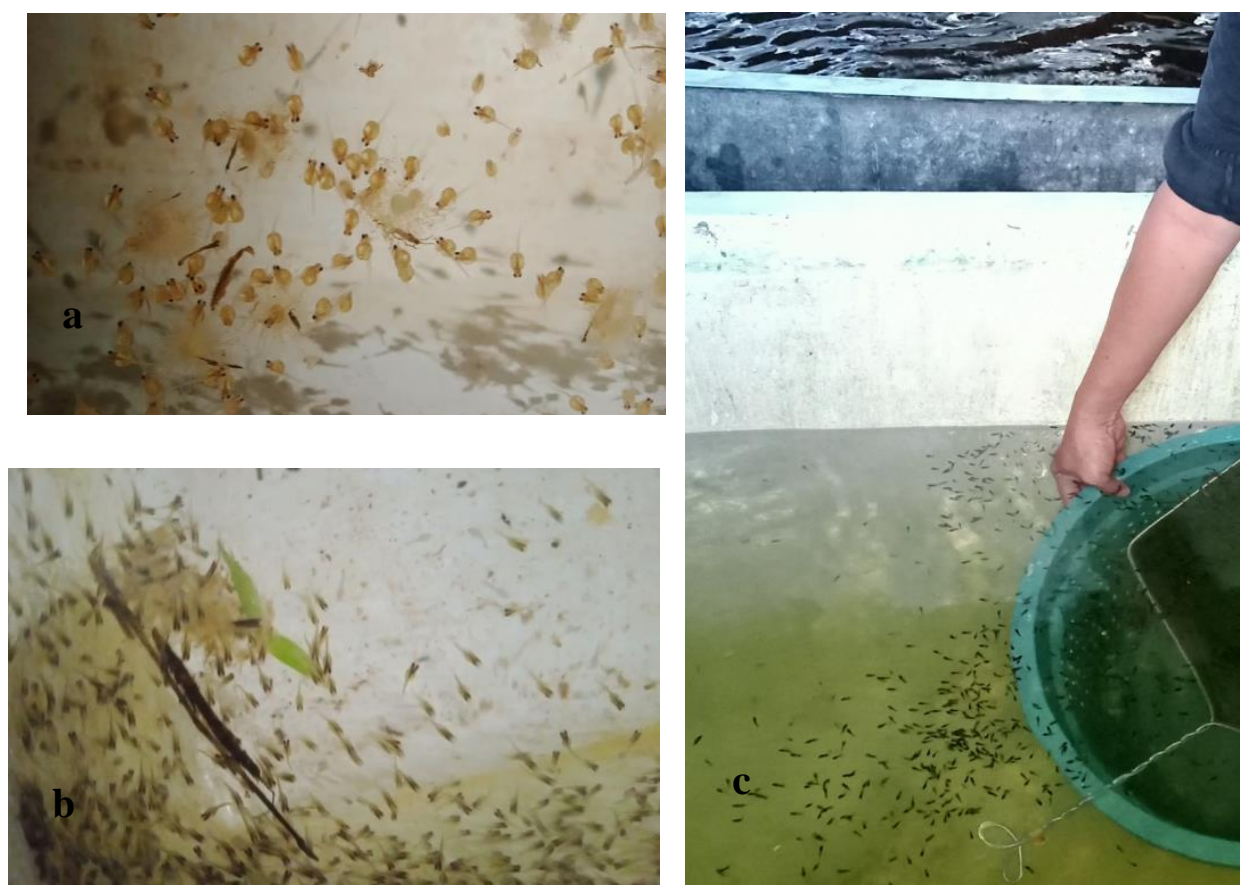

Gambar 3. Panen telur gurame dan pemeliharaan benih gurame (a) 0, (b) 10 dan (c) 25 hari

c. Tahap pembesaran yaitu tahap pemeliharaan benih gurami sejak umur 3 bulan atau berat 1 gram akan dibesarkan dan dilakukan sampling dan sortir ukuran benih seragam setiap bulan (Gambar 4).
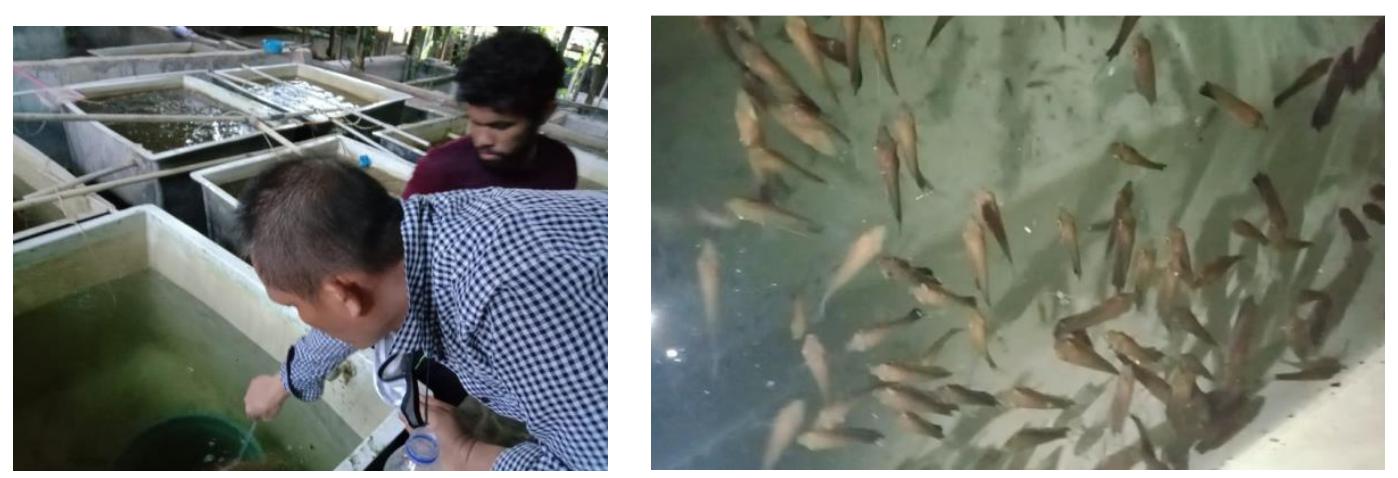

Gambar 4. demplot system budidaya resirkulasi dan pendampingan pemeliharaan benih umur 2, 3 dan 4 bulan pada system resirkulasi dengan kepadatan 600 dan 800 benih dan diberi pakan formlasi komersial 

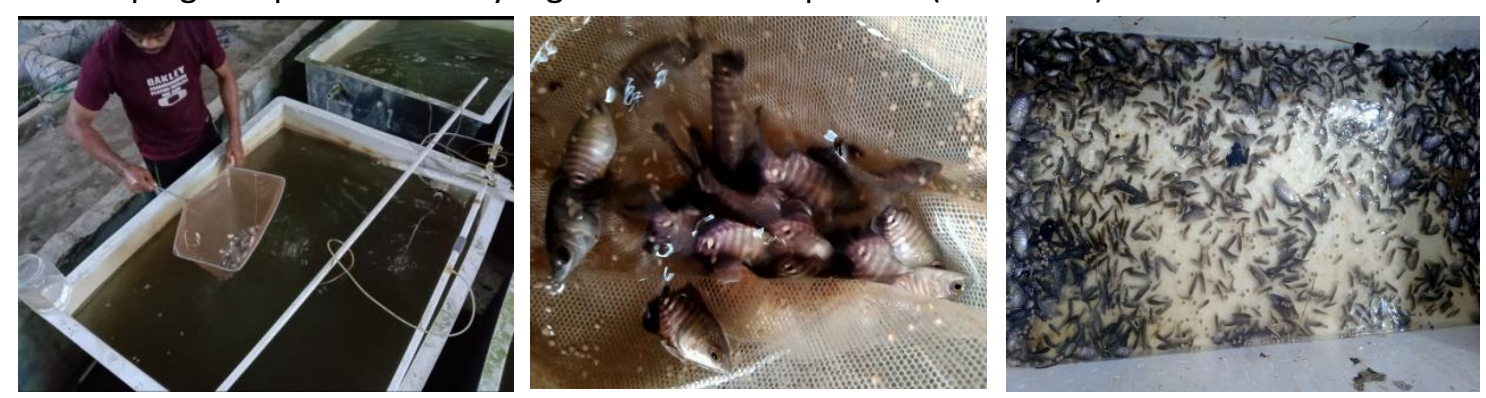

Gambar 5. Panen dan seleksi/sortir ukuran benih seragam untuk penjualan

\section{Hasil pemijahan induk (telur dan larva)}

Sistem budidaya resirkulasi secara ekonomi menguntungkan untuk penggunaan lahan dan jumlah air pada pemeliharaan induk dan benih sangat jauh lebih hemat sehingga kolam dapat dimanfaatkan secara maksimal untuk memeliharaan induk dan benih ytang dihasilkan dengan kepadatan tinggi dan tidak mengganggu pertumbuhan benih dan siklus reproduksi induk. Pada damplot system resirkulasi, induk telah dipelihara dengan menggunakan pakan formulasi secara intensif dan diberi pakan tambahan daun keladi setiap 2 minggu sekali secukupnya dapat hidup dan pemijahan tetap berlangsung karena kualitas airnya tetap baik.

Pada kolam induk masing-masing kelompok pembudidaya memelihara 12 induk betina dan 3 induk jantan. Pakan yang diberikan adalah pakan komersial dan diberi pakan tambahan daun santé / talas. Induk dipelihara sampai menghasilkan benih. Pada kolam akan ditempatkan 4 sarang berbentuk kerucut untuk tempat induk bertelur.

Pemeliharaan induk dapat dilakukan pada ukuran kolam $3 \times 2$ sebanyak 6 induk ( 2 jantan dan 4 betina) dan pada kolam 2 sebanyak 9 induk ( 3 jantan dan 6 betina) dengan kedalaman air masingmasing $80 \mathrm{~cm}$. Jika dibandingkan sebelumnya, induk dipelihara pada kolam yang luas $6 \times 20$ meter atau $20 \times 25$ meter. Dengan system RAS ini pemanfaatan lahan dan jumlah air sangat kecil. Selama pelaksanaan PKM ini sudah 8 induk memijah sejak Mei sampai September 2021.

Setelah pemasangan keranjang tempat sarang induk gurame dipasang, rumput kering ditambakan ke dalam kolam pemijahan induk. Penetasan telur gurami dimulai setelah sarang berisi telur. Pada Damplot PKM, induk gurame memijah pada siang hari sehingga pengambilan telur terbuahi dilakukan esok pada pukul 06.00 pagi hari. Telur gurami kemudian diinkubasi dalam bak pemijahan berisi 150 liter air. Telur tersebut menetas setelah $50-90$ jam sejak pemijahan. setelah menetas telur yang berubah menjadi larva dengan kuning telur hingga berumur 8 hari. Pada saat ini larva tidak perlu dikasih makan. Setelah 8 hari, larva dipindahkan ke bak kapasitas 1000 liter berisi 500 I untuk pemeliharaan larva dengan kepadatan 3000-5000 benih umur 8 hari dan diberi pakan Moina sp. Selanjutnya benih diberi pakan moina sp. sampai umur 45-55 hari.

Selama masa pemeliharaan mulai 3 Mei sampai bulan September 2021, induk yang memijah sebanyak 8 induk dengan jumlah produksi telur dan benih yang dihasilkan adalah sebagai berikut: 
Tabel 1. Waktu memijah, jumlah telur dan jumlah benih yang dihasilkan (Manfaat yang diperoleh setelah penerapan system budidaya RAS dan pemberian Pakan formulasi secara intensif pada induk Gurame yang dipelihara pada kolam $2 \times 3$ meter)

\begin{tabular}{lllll}
\hline Tanggal Memijah & No. Kolam & Jumlah telur & Benih & Menetas (\%) \\
\hline 28 Mei 2021 & 1 & 1765 & 976 & 55.3 \\
3 Juni 2021 & 2 & 1521 & 955 & 62,8 \\
7 Juni 2021 & 2 & 2852 & 1520 & 59,6 \\
3 Juli 2021 & 2 & 2459 & 1332 & 54,2 \\
9 Juli 2021 & 1 & 2385 & 1152 & 48,3 \\
10 Agustus & 1 & 1742 & 1103 & 63,32 \\
26 Agustus 2021 & 1 & 3358 & 3051 & 90,86 \\
2 September 2021 & 1 & 3124 & 2967 & 94,97 \\
\hline
\end{tabular}

\section{Pembesaran benih gurame}

Tahap pembenihan yang mencakup tahap pemijahan, penetesan telur dan perawatan larva. Telur yang telah menetas dari induknya dipelihara hingga menjadi larva dengan berat 0,1 gram selama 1 bulan. Sekitar 8800 benih gurame umur 1 bulan sampai 4 bulan dipelihara pada bak / kolam larva/benih selama 1-2 bulan.

Pada UKM mitra PKM, Pembesaran larva terdiri atas fase pemijahan dan fase pendederan. Pendederan pertama adalah pemeliharaan larva ukuran 0,75-1 cm dan pemeliharaan benih ukuran 1$2 \mathrm{~cm}$ (dari umur 8-55 hari). Pendederan kedua adalah pemeliharaan benih ukuran 2-4 cm (umur $>55-$ 90). Pendederan ketiga adalah pemeliharaan benih hasil pemeliharaan pendederan kedua (ukuran 46) dan hasil sortir benih yang ukuraannya seragam. Hal ini sesuai dengan SNI (2000).

Setelah berumur 55 hari benih gurame yang berukuran besar dipisahkan dengan yang berukuran kecil. Benih gurame berumur 55 hari atau lebih yang berukuran besar selanjutnya diberi pakan formulasi Prima Feed (pf 500) karena ukuran pakan sudah sesuai bukaan mulut benih. Adapun hasil pemeliharaan benih gurame secara intensif pada demplot system resirkulasi dapat dilihat pada Table 2 dan Table 3 berikut.

Tabel 2. jumlah benih yang dipelihara pada bak fiber1 ton system budidaya Resairkulasi dan pemberian Pakan formulasi secara intensif, pertumbuhan dan sintasannya setiap kali sampling

\begin{tabular}{llccclc}
\hline $\begin{array}{l}\text { Tanggal } \\
\text { tebar }\end{array}$ & $\begin{array}{l}\text { No } \\
\text { bak }\end{array}$ & $\begin{array}{c}\text { Jumlah } \\
\text { tebar }\end{array}$ & \multicolumn{2}{c}{$\begin{array}{l}\text { Tanggal sampling /ukuran benih } \\
\text { (Panjang }(\mathrm{mm}) / \text { berat }(\mathrm{g}))\end{array}$} & Sintasan & \\
\cline { 4 - 7 } & & & $02 / 10 / 2021$ & $2 / 11 / 2021$ & Jumlah & $(\%)$ \\
\hline $02 / 09 / 2021$ & 1 & 600 & $67,09 / 5,66$ & $96,75 / 8,605$ & 576 & 96 \\
$02 / 09 / 2021$ & 2 & 600 & $65,17 / 4,68$ & $70,66 / 6,91$ & 584 & 97,3 \\
$02 / 09 / 2021$ & 3 & 800 & $56,9 / 2,86$ & $69,8 / 5,333$ & 758 & 94,75 \\
$01 / 09 / 2021$ & 4 & 2967 & $17,36 / 0,108$ & $30,435 / 1,05$ & Belum dihitung \\
$09 / 09 / 2021$ & 5 & 2896 & $14,145 / 0,094$ & $23,36 / 0,511$ & Belum dihitung \\
$09 / 10 / 2021$ & 6 & 800 & $41,375 / 1,58$ & $47,7 / 2,316$ & Belum dihitung \\
\hline
\end{tabular}


Tabel 3. Pesentase Jumlah keseragaman benih yang dipelihara pada system budidaya RAS dengan kepadatan berbeda dengan pemberian Pakan formulasi komersial menngunakan bak fiber 1 ton

\begin{tabular}{llllll}
\hline $\begin{array}{l}\text { Tanggal } \\
\text { tebar }\end{array}$ & $\begin{array}{l}\text { No } \\
\text { bak }\end{array}$ & $\begin{array}{l}\text { Jumlah } \\
\text { tebar }\end{array}$ & \multicolumn{2}{l}{ Keseragaman ukuran benih } & Sintasan (\%) \\
\cline { 4 - 6 } & & & Jumlah & Jumlah & $\mathrm{K}(\mathrm{mm}) \quad \mathrm{B}(\mathrm{mm})$ \\
\hline $02 / 09 / 2021$ & 1 & 600 & 391 (Kecil) & 185 (besar) & $65,230,83$ \\
$02 / 09 / 2021$ & 2 & 600 & 428 (Kecil) & 156 (besar) & $71,526,0$ \\
$02 / 09 / 2021$ & 3 & 800 & 617 (Kecil) & 141 (besar) & $77,1017,63$ \\
$01 / 09 / 2021$ & 4 & 3051 & $17,36 / 0,108$ & $30,435 / 1,05$ & Belum dihitung \\
$09 / 09 / 2021$ & 5 & 2967 & $14,145 / 0,094$ & $23,36 / 0,511$ & Belum dihitung \\
$09 / 10 / 2021$ & 6 & 800 & $41,375 / 1,58$ & $47,7 / 2,316$ & Belum dihitung \\
\hline
\end{tabular}

Pendederan tahap pertama pada system resirkulasi adalah kegiatan pemeliharaan benih berukuran $2 \mathrm{~cm}$ berumur $>55$ hari dan bukaan mulutnya sudah bisa measukkan pakan no 1000 . Pada Table 2 diketaui bahwa pemeliharaan benih gurame umur 3 bulan dan 4 bulan dengan kepadatan berbeda pada system resirkulasi memberikan pengaruh yang berbeda pertumbuhan dan sintasan benih ikan gurame.

Hasil pemeliharaan benih gurame dengan kepadatan 600 dan 800 benih ukuran $3 \mathrm{~cm}$ (ratarata berat ) pada system budidaya resirkulasi menunjukkan bahwa Hasil penerapan RAS pada Mitra PKM diketahui bahwa dengan sistem konvensional dengan padat tebar benih hanya 0,2 ekor per liter sedangkan pendederan ikan gurame dengan teknologi Resirkulasi dengan penggunaan pakan formulasi bisa mencapai padat tebar pada umur benih 8-20 hari (15-25/ liter atau 3000-5000/150200liter air) sedangkan padat tebar benih umur 20-55 hari sekitar (6 ekor/liter). Kemudian pada ukuran 4-6 cm padat tebar pada damplot system resirkulasi PKM (0,9-1 ekor/liter atau 800 ekor/900 liter). Keuntungan lainnya, masa pemeliharaan benih menjadi relatif lebih pendek yaitu pada usia 30 hari telah mencapai ukuran 2-4 cm. Dengan tingkat kelulusan hidup mencapai $94-96 \%$ dan tingkat keseragaman ukuran hingga 65-77 \%, tergantung padat penebaran yang digunakan.

Alasan dan manfaat membagi budidaya ikan dalam tahapan tersebut diatas dan melakukan sampling setiap bulan adalah: 1 . Membudidayakan ikan gurami sampai dengan ukuran konsumsi memakan waktu cukup lama sehingga perolehan hasil usaha dirasakan cukup lama; 2.Permintaan produk untuk setiap tahapan (dalam bentuk telur, benih dan ikan ukuran konsumsi) cukup tinggi;3. Keterbatasan modal dan lahan usaha apabila pembudidaya harus melaksanakan tahapan dalam satu siklus penuh

Dengan pembagian tahapan ini telah membantu kelompok pembudidaya ikan gurami binaan kegiatan PKM mengelola kegiatan budidayanya semakin baik. Dalam hal ini :Mempersingkat masa panen; Menghasilkan pendapatan pembudidaya dengan keuntungan yang cukup memadai dan Menurunkan resiko kegagalan panen. Berdasarkan penjelasan diatas penggunaan sitem resirkulasi dengan penambahan filter menunjukan hasil yang baik pada pertumbuhan dan sintasan ikan gurame. Hal ini menunjukkan bahwa kualitas air pada system Resirkulasi yang diterapkan pada damplot PKM ini mendkung untuk budidaya induk dan benih gurame. 


\section{KESIMPULAN DAN SARAN}

Kesimpulan

1. Penerapan system Budidaya RAS untuk pemeliharaan induk gurami secara intensif pada kegiatan PKM ini meenunjukkan hasil yang sangat baik Dengan system RAS ini kegiatan budidaya gurami secara intensif dapat dilakukan dengan pemanfaatan lahan dan jumlah air sangat kecil.

2. pembesaran benih gurame mulai umu 60 hari (ukuran $2-3 \mathrm{~cm}$ dan benih ukuran $(4-6 \mathrm{~cm})$ dapat dilakukan dengan kepadatan 600-800 ekor benih/900 liter air pada sitem resirkulasi dan akan menghasilkan pertumbuhan, sintasan dan kualitas air yang mendukung selama 3 bulan masa budidaya.

3. Pemanfaatan Pakan formulasi memberikan hasil yang lebih baik yaitu hamper setiap bulan ada induk yang memijah pada setiap kolam selama masa pemeliharaan induk dan benih yang dipelihara menunjukkan pertumbuhan dan sistasan yang tinggi.

4. Kegiatan percontohan demplot system budidaya resirkulasi untuk intensifikasi budidaya gurame pada PKM ini, telah menunjukkan hasil produksi dan budidaya massal benih gurame dengan pertumbuhan dan sintasan yang dihasilkan tinggi pada setiap tahap pendederan serta memberikan keuntungan yang sangat memuaskan bagi Mitra PKM.

Saran

1. System inkubasi telur dari gurami akan diperbaiki untuk menghasilkan produksi benih yang lebih tinggi

2. Penerapan system budidaya RAS untuk pemeliharaan indukdan benih bisa diujicobakan pada lahan yang lebih luas dan kepadatan yang lebih tinggi..

\section{UCAPAN TERIMA KASIH}

Penulis mengucapkan terima kasih kepada DRPM Kemendikbud Ristek Dikti yang telah memberi dukungan financial terhadap pengabdian Program Kemitraan Masyarakat ini.

\section{DAFTAR PUSTAKA}

Allen, P.D. 2017. An Overview of Aquaponic Systems: Aquaculture Components. NCRAC Technical Bulletins. New Zealand Article.ISSN:1176-5402;1176-8657.

BSN. Standar Nasional Indonesia. 2000. SNI : 6485.2-2000. Benih Ikan Gurami

Dalsgaard, J., Lund, I., Thorarinsdottir, R., Drengstig, A., Arvonen, K., \& Pedersen, P.B. (2013). Farming different species in RAS in Nordic countries: Current status and future perspectives. Journal of Aquacultural Engineering, 53, 2-13.

Drengstig, A., \& Bergheim, A. (2013). Commercial land-based farming of European lobster (Homarus gammarus L.) in Recirculating Aquaculture System (RAS) using a single cage approach. Journal of Aquacultural Engineering, 53, 14-18.

Jeffery K., N. Stinton \& T. Ellis. 2011. FES220: A Review Of The Land-Based, Warm-Water Recirculation Fish Farm Sector In England And Wales. Cefas Weymouth Lab, Barrack Road, The Nothe, Weymouth, Dorset, DT4 8UB. Cefas contract report $<C 3529\rangle$.

Jumaidi A. 2016 Pengaruh Debit Air Terhadap Perbaikan Kualitas Air Pada Sistem Resirkulasi Dan Hubungannya Dengan Sintasan Dan Pertumbuhan Benih Ikan Gurame (Oshpronemus gouramy).e-Jurnal Rekayasa dan Teknologi Budidaya Perairan. Volume V No 1 Oktober 2016. ISSN: 2302-3600. (c) e-JRTBP Volume 5 No 2 Februari 2017.

Norjanna F, Efendi E, Hasani Q. 2015. Reduksi amonia pada sistem resirkulasi dengan pengunaan filter 
yang berbeda. e-Jurnal Rekayasa dan Teknologi Budi daya Perairan, 4(1): 427-432.

Pusat Pengkajian dan Perekayasaan Teknologi Kelautan dan Perikanan [P3TKP]. (2013). Laporan akhir penelitian rekayasa shelter untuk pendederan air laut. Jakarta: Kementerian Kelautan dan Perikanan.

Sulistyo J, Muarif M, Mumpuni FS. 2017. Pertumbuhan dan kelangsungan hidup benih ikan gurami (Osphronemus gouramy) pada sistem resirkulasi dengan padat tebar 5,7 dan 9 ekor/liter. Jurnal Pertanian, 7(2): 87-93.

Thesiana L Dan A. Pamungkas. Uji Performansi Teknologi Recirculating Aquaculture System (Ras) Terhadap Kondisi Kualitas Air Pada Pendederan Lobster Pasir Panulirus Homarus. Jurnal Kelautan Nasional, Vol. 10, No. 2, Agustus 2015, Hal. 65-73.

Verawati. 2017. Pengaruh perbedaan padat penebaran terhadap pertumbuhan dan kelangsungan hidup benih ikan gurami (Osphronemus gouramy) pada sistem resirkulasi. Jurnal Mina Sains, 1(1): 6-12.

Qiu, T, L. Liu, M. Gao, L Zhang, H. Tursun and X. Wang. 2016 . Effects of solid-phase denitrification on the nitrate removal and bacterial community structure in recirculating aquaculture system. Biodegradation 2016, 27, 165-178.

Zhu, S., J. Shen, Y. Ruan, X. Guo., Z. Ye.,Y. Deng., and M. Shi. 2016 The effects of different seeding ratios on nitrification performance and biofilm formation in marine recirculating aquaculture system biofilter. Environ. Sci. Pollut. Res. 2016, 23, 14540-14548.

BSN. Standar Nasional Indonesia. SNI 01-7241-2006. Produksi ikan gurami (Osphronemous goramy Lac.) kelas pembesaran di kolam 